\title{
Radical Historicism or Rules of Reproduction? New Debates in Political Marxism
}

\section{Symposium Introduction for Historical Materialism 29.3 (2021)}

Maïa Pal

\begin{abstract}
This introduction presents the symposium on Sam Knafo and Benno Teschke's article in Historical Materialism 'Political Marxism and the Rules of Reproduction of Capitalism: A Historicist Critique' (2021). It briefly summarises the foundations of Political Marxism, discusses the broader implications of the debate raised by Knafo and Teschke for questions of collective knowledge production and methods in Marxist historiography, and outlines the seven contributions of the symposium. The introduction concludes by tracing, through the evolution of debates in Political Marxism and the contributions of its protagonists, some of the lineages of Marxist historiography as well as of the history of this journal.
\end{abstract}

Keywords: Political Marxism, Social Property Relations, Historical Sociology, Structuralism, Rules of Reproduction, Radical Historicism, Agency, Method, Historiography

Despite decades of sophisticated Marxist theory, the existence of capitalism remains, as Søren Mau shows in the previous pages of this issue, if not 'a mystery, at least paradoxical'. ${ }^{1}$ Yet the following symposium certainly testifies to the continuing richness and perseverance of scholars to get to the mysteries of its origins. Political Marxism, the approach that most of the contributors in this symposium adhere to, either as Capital-centric Marxism, or as a specific method for international historical sociology, has been shaped by attempts to be as specific as possible regarding the historical emergence of capitalist social property relations, one of its key conceptual contributions to Marxist historiography.

Although reluctantly branded as the founders of Political Marxism, Robert Brenner and Ellen Meiksins Wood nevertheless led the way and continue to inspire new generations of scholars. ${ }^{2}$ In many ways, this symposium is a celebration of, and witness to, the passing of different generations of scholarship. It links different epochs and debates in Marxism to issues in the social sciences more generally. However, it also speaks to the history of this journal. Before discussing how in more detail below, the following briefly presents Political Marxism and its key contributions.

Political Marxism has a strange footing in what can be called the Marxist landscape. Embedded in the Western Marxist tradition, it emerges as a loud battle cry against what its founders identified as two heresies plaguing twentieth century Marxism: structuralism and economic determinism. The first 'Brenner debate' on the transition from feudalism to capitalism laid the historical foundations for what came to be known as 'Political Marxism', an approach thereafter theorised most explicitly by Ellen Meiksins Wood. In what have become famous passages, Wood lays out the basic principles of an approach that aims to rid Marxism

\footnotetext{
${ }^{1} \operatorname{Mau}(2021: \mathrm{x})$

2 Brenner, 1976; Brenner, 1977; Aston \& Philpin, 1995; Wood, 1981; Wood, 1995.
} 
of some of its remaining socially-scientific bourgeois tendencies, encapsulated by the misgivings of the 'commercialisation model' and other false dichotomies that generate limited accounts of the origin and development of capitalism. ${ }^{3}$

Wood provides fresh definitions of the notions of 'base' and 'superstructure'; of the mode of production; of the political, economic, and social; and of what it means to take a 'practical' theoretical stance. ${ }^{4}$ Crucially, she manages to provide an account that goes back to the basics of materialism, which for her is 'an understanding of the social activity and the social relations through which human beings interact with nature in producing the conditions of life' as well as an 'historical understanding which acknowledges that the products of social activity, the forms of social interaction produced by human beings, themselves become material forces, no less than are natural givens. ${ }^{5}$ From this starting point, she can then assert that a mode of production is a more complex process, a 'continuous structure of social relations' ${ }^{6}$ involving the 'social organization of productive activity', whereas a 'mode of exploitation is a relationship of power', which in turn is 'a matter of political organization within and between the contending classes'. ${ }^{7}$ This political organization is always contested and constitutes relations of production (or social property relations) through the struggles between appropriators and producers. These starting points render more economistic, commercially-based, and naturally given accounts of the relation between the political and economic - found in contending approaches to Marxism in the 1970s and 1980s - historically weak and conceptually limited to the illusions produced by capitalism itself, and are hence reduced to bourgeois fallacies by Wood.

The common ground derived from these passages and shared by Political Marxists, as you will see below, remains at the forefront of the debates that follow, but also has become a new area of dispute. Is the structuralism of the 1970s - which E.P. Thompson famously railed against and which Political Marxists all agree was deeply problematic - still a problem today? ${ }^{8}$ Sam Knafo and Benno Teschke, whose article is at the centre of this symposium, take aim at a new manifestation of a structuralism they find present today in other Political Marxists' work, notably through the concept of the rules of reproduction, and this argument is hotly contested especially by Charles Post, Xavier Lafrance, Mike Žmolek, and Jessica Evans. ${ }^{9}$

In contrast, the issue of rejecting economic determinism and of emphasising the politically contested - and constituted - dimension of capitalist social property relations remains an accepted starting point between all contributors. However, as Heide Gerstenberger's piece reminds us, writing as a sympathetic outsider to Political Marxism, what this politically contested and constituted dimension is, whether as state or class power, needs to be further discussed and appreciated by Political Marxists in the context of other debates in Marxist historiography. Furthermore, as Javi Moreno Zacarés and Pedro Salgado respectively discuss

\footnotetext{
${ }^{3}$ Wood, 1995: 23-28

4 Wood, 1995: 25

5 Wood, 1995: 26.

6 Wood, 1995: 25

7 Wood, 1995: 27

8 See Post (2021: 3-5), Lafrance (2021: 3), and Žmolek (2021: 2) for discussions of Althusser's structuralism.

${ }^{9}$ Knafo and Teschke, 2021a. The authors cited have all published landmark works identifying as, or associated with, Political Marxism, e.g. Teschke, 2003; Knafo, 2013; Post, 2011a; Žmolek, 2014; Evans, 2019; Lafrance, 2019.
} 
in each of their contributions, Political Marxism needs to engage more with how it situates itself in broader debates in the social sciences, notably historical institutionalism and post/ decolonial theory. ${ }^{10}$

In effect, the 'strange footing', alluded to above, of Political Marxism in the broader family that we call historical materialism, refers to this political vs economic relation and the occasional incomprehension that some Marxists have for how Political Marxism proposes to focus on the concept of 'social property relations' instead of 'relations of production'. ${ }^{11}$ Usual misconceptions are 1) that this conception is merely about the political forms and interactions through which economic actors and forces manifest themselves, thus falsely assuming that the concept of social property relations reifies the political and reverses to a political determinism; 2) that the only and/or primary process that Political Marxists are concerned with to define capitalism is wage-labour as it appears in market conditions of dependence between actors separated from their means of production, thus significantly reducing the definition to an ideal-type case that exceptionalises England and, in the worst cases, produces a Eurocentric and racist history of capitalism.

Instead, Political Marxist scholars have continuously stressed that social property relations refer to the ensemble of political and economic, as well as juridical, administrative, cultural, religious, etc. relations that constitute, through a range of class struggles, the conditions of capitalist development. Moreover, in relation to the second misconception, wage-labour is indeed used to define capitalism as it emerged in sixteenth-seventeenth century England. However, it is also crucially understood in the context of being politically constituted and contested through the specific development of the English Crown-in-Parliament and the specific class struggles of the different waves of enclosures that shaped the distribution of land and resources in early modern England. Moreover, as Dimmock argues, specific regions such as Kent even saw earlier processes of enclosures in the fourteenth century that laid crucial foundations for later processes of dispossession usually ascribed to the emergence of capitalism. $^{12}$

These misconceptions are frustrating. They tend to ignore or forget the crucial theoretical and ground clearing work done by Brenner and Wood, and especially Wood, on the separation of the political and economic. ${ }^{13}$ Secondly, they ignore discussions on the need to foreground any social history in careful and meticulous specificity that does not assume a general law of development or a teleological search for a given phenomenon - for example, consequentialist historians are, for Political Marxists, especially guilty of this mistake. ${ }^{14}$ Instead, the method of Political Marxism, if one agrees to there being one, is foremost to move away from a pre-given set of assumptions about historical development, and to not fetishize economic or political

\footnotetext{
${ }^{10}$ For these authors' previous key contributions to Political Marxism, see Moreno Zacarés (2018) and Salgado (2020).

11 Defined originally by Brenner (2007: 58), social property relations are understood as 'the relations among direct producers, relations among exploiters, and relations between exploiters and direct producers that, taken together, make possible/specify the regular access of individuals and families to the means of production (land, labour, tools) and/or the social product per se.'

12 Dimmock, 2014

13 Wood, 1981

${ }^{14}$ For an excellent summary of the genealogy, recent contributions of, and challenges faced by Political Marxism, see Lafrance \& Post (2019a). For new scholarship in Political Marxism looking at agrarian revolutions, see Bøgh Sørensen (2019; 2021).
} 
relations as if they were universally and ahistorically given as fixed concepts that need no explanation and merely serve as explanatory devices. Now, as we will see below, the extent to which Political Marxism does function with a set of pre-given assumptions is at the core of debates in this symposium, and these debates are shaping the direction of what some may call 'Political Marxism 2.0'. In this sense, Knafo and Teschke's article has generated some strong reactions, and thus deserves to be the basis for these discussions around what it means to do Political Marxist work today.

Another reason why this symposium is an important and crucial exercise that should interest historical materialists and socialists more widely, is that asking the question of the relevance of historical and historiographical debates on the transition to capitalism, in a world of crises and catastrophes, is one that will always need reiterating and answering. Political Marxists are not antiquarian historians concerned with the specific issues of a bygone era. Questions of transition, of historical method, of what 'history' means for a Marxist, change with each generation and are as central to small academic circles, as they are to conversations down the pub about the state of the world. Questions and debates about historical revisionism and colonial reparations, from territorial claims to statues and school textbooks, are occurring across the world. Critical race theories are targeted by governments and some critical scholarship is being silenced or engaged in dirty online battles. Even academia is being shaken by scandals over scholarship considered racist, or white apologist, and journals are fighting libel accusations for publishing arguments that simply apply common ideas in critical theory about structural racism. History remains, as always, deeply political and politicised by various corners of the political spectrum.

How can Political Marxism, if at all, contribute to these debates and to bringing some sense to how common narratives of capitalism are constructed in mainstream debates? What would be Political Marxism's slogan for its participation in the culture wars? Perhaps it is wise to stay out of these often toxic and circular debates, but these questions do raise the issue of why this specific approach matters beyond the richness of academic circles. Moreover, the concepts of racial capitalism and settler colonialism are becoming more widely used, and surely Political Marxism can bring precious clarifications to how these structures, rules, practices, or lineages of social property relations fit into their narratives of emergence and expansion.

For Wood, grounding her work on the origins of capitalism as the basis to her everyday socialism was absolutely essential to determining struggles within capitalism today, to understand the role of the state, of how intellectuals could help to imagine a transition out of capitalism, and how workers could position themselves in a historical continuum that was not pre-determined. These questions need to be revisited for our time, and many contributors in this symposium are involved in everyday political and editorial struggles, for which their approach to Political Marxism possibly informs their positions and choices. Perhaps more openness of these might help re-enliven the debates about why and how Political Marxism matters. ${ }^{15}$

${ }^{15}$ For an example of such a contribution, see interviews of Benno Teschke and of Charlie Post by Souvlis (2019). 
Indeed, Political Marxism has been accused at times, perhaps ironically, of political inertia. Regardless of whether this accusation is justified, we all have a duty to question the projects we embark on and explain what they mean to us, politically or strategically. Perhaps Political Marxists have been less keen to do so, assuming that the benefits of historical enterprise were obvious. Helpfully, the contributions that follow raise some of these questions. In their reply, Knafo and Teschke respond by rejecting that their argument leads to a form of 'bland liberal pluralism' and argue that 'the power of critique' should be disentangled, or at least not automatically inferred, from certain abstract methodological positions:

we know of these problems [e.g. the exploitation of migrant workers] because of empirical/historical work that documents them, not because the rules of reproduction tell us what to think about them. We should have more faith in our political judgement instead of relying on abstract rules of reproduction as our moral compass. ${ }^{16}$

In a sense, there is a tension here between, on the one hand, the rigour that all contributors below explicitly demonstrate and demand of each other - and one they argue tends to be lacking in other attempts to historicise capitalism, a point they can definitely all agree on. On the other hand, something in this comment remains very difficult to logically and definitively map, something mysterious, mute even perhaps. How do we consciously develop our conceptual apparatuses? Are we honest and clear with ourselves about when and how we do so? How do we integrate our 'political judgement', if clearly separated from our abstract apparatuses, and when does it need to take a back seat, or take over the driving? Knafo and Teschke very interestingly clarify that they do not mean that Brenner 'consciously' took a structuralist turn, followed by their tongue-in-cheek comment 'who would?' Instead, they argue that ambiguities in the foundational promises and travails of Political Marxism meant that structuralist tendencies were to some extent inevitable. The founders are thereby excused of their wrong turns and, more importantly, an argument is made about knowledge production and the complexities, and mysteries, of its inner mechanisms and forces. Crucially, they argue that we 'should not assume that we know what is at stake politically before we turn to history' and provide here a helpful way to translate their methodological arguments about historiography to more everyday practices. ${ }^{17}$

Without trying to open a new set of issues about the lived agency and self-consciousness of the intellectual, these exchanges and clarifications speak to a central conclusion arising from this symposium. Individual processes of conceptualisation and historicisation (also known as the project of historical materialism) are always part of a collective, dialogical, and contested wider process. Debating these may seem or even need to be out of time and place (e.g. why does any of this matter if the planet is burning?), but the wider process and project of historical materialism regularly requires this collective - if momentary - abstraction from everyday struggles to pin down a specific problem of method.

However, some readers may lift their noses up at these debates, accusing the protagonists of having descended into dark and dead-end caves. Others will hopefully consider that, albeit intra-circular to some extent to the Political Marxist realm, they raise crucial problems of history and theory that can illuminate many other Marxist debates. Some might even consider that

\footnotetext{
16 Knafo \& Teschke, 2021b: X

17 Ibid.
} 
these are some of the most important and deeper epistemological conversations currently occurring. For example, what are the purposes, and crucially the limits, of theory for Marxism? What concessions do we allow theory when we embark on - and later often drag our way through - a research project? Are we always consistent with our methods, and who is the best judge of this, ourselves or our peers and readers? Are we conscious of the mistakes and tendencies we fall into? And is this evaluation of the founders of the tradition we follow a necessary process? For Žmolek, it is quite the opposite; he wonders at why anyone would want to question one's founders through such a 'harsh critique'. ${ }^{18}$ Perhaps this process is not so straightforward, and shows that scholars' relations to those they acknowledge as founders remains complicated. Ultimately, this relationship may be more about evaluating one's own scholarship (and its relationship to the emergence of one's knowledge and methods) as this emergence is often a blind and dedicated faith in the method of the founders chosen, rather than a careful and systematic elimination of all other possible candidates. ${ }^{19}$ Thus, by retracing the structuralist ambiguities in Brenner and Wood as the founders of Political Marxism, and how these ambiguities and antinomies developed in the concept of the rules of reproduction, Knafo and Teschke are also holding up a mirror to their own relationship with these ambiguities and to the evolution of their own thinking.

In other words, this symposium is a chance to think about the implications of the research decisions we make, of what it means to assert one's method as more or less structuralist or agential in a context where these words seem to take unendingly different meanings from one theory, let alone one discipline, to the next. Also, what does it mean to engage in conceptual debates and to what extent do we need agreed baselines to conduct research and/or collectively identify as a specific school or tradition? I take these debates to be an opportunity to remind ourselves that the fun is in the game, or in some cases perhaps, the contest, and not (merely) in who wins the academic argument. If there is a tendency in Marxist debates on the transition to capitalism to play the game of 'my capitalism is bigger than yours' (or in this case, 'my agency is better than yours') - in which the high number of male participants may not be a coincidence - surely it is more than time to loudly assert that we may be missing the point by playing to win that game. Thankfully, the richness and collegiality of the debates below, and the certainty that they will lead to helping other scholars and generations navigate their way through how to historicise capitalism, make me confident that this is a collective endeavour that will strengthen Political Marxism rather than the early signs of a schism.

Yet as work in Political Marxism grows, applying and nuancing its core ideas in various temporal and spatial contexts, and as the critiques and perhaps in some cases misunderstandings take a strong form, it is definitely time to ask some difficult conceptual questions and deal with the problem of Political Marxism being less 'identifiable', as Knafo and Teschke note. ${ }^{20}$

For example, a fundamental question is, if we want to take up Knafo and Teschke's radical historicist method, whether we, and our capitalist subjectivity, can escape tendencies to think structurally? Is this tendency not a product of our capitalist subjectivity, i.e. may this debate

\footnotetext{
18 Žmolek, 2021: 2.

19 Moreno Zacarés (2021: 17) also reads the debate as more of an 'evolution of their [Knafo and Teschke's] own research agendas'.

${ }^{20}$ Knafo \& Teschke (2021b: $\left.\mathrm{x}\right)$
} 
not be specific to knowledge production in a capitalist economy where intellectual labour is fragmented, institutionally driven, and severely limited by the inequalities reproduced by those institutions?

To answer these questions, we need to note the difference between those who have a stake in these debates (either because they adopt one of the labels of Political or Capital-centric Marxism, or because they have specific grievances about them), and those who do not have a stake and see these debates as illustrative of bigger issues in Marxist historiography. In other words, if the debates are about method and subjectivity in knowledge production, they are also about situating and signalling one's originality in a collective, or perhaps against it. We must acknowledge that the debates can be confusing and disheartening to newcomers, and thus we have a duty to relate these discussions back to what essentially unites us. For example, when Campling and Colás (2021) in their new study on capitalism and the 'maritime factor' briefly survey current debates in Marxist historiography, they note the presence of an 'analytical juncture' where two approaches are 'on offer': one focusing on 'overseas trade and war', 'capital circulation', and 'merchants and maritime commerce'; and the other on 'commodification of social relations in the English countryside', 'production of surplus value', and 'commodified agriculture'. ${ }^{21}$

We clearly see in the first category here, with inevitable nuances, the work of Jairus Banaji, Markus Rediker and Peter Linebaugh, Jason Moore, Laleh Khalili, Silvia Federici, Pepjin Brandon, Giovanni Arrighi and the legacy of Fernand Braudel and Immanuel Wallerstein. ${ }^{22}$ This work remains crucial in highlighting aspects of the emergence of modernity that particularly resonate with the contemporary mechanisms of capitalist accumulation associated with logistics and a plurality of actors and contexts that defy any single standpoint narrative. The second category refers most characteristically to Political Marxism, though perhaps some proponents of Uneven and Combined Development and of international historical sociology might also see themselves fitting this category. In any case, for Campling and Colás, it is 'possible and desirable' to accept 'both approaches to be right, at least in part'. ${ }^{23}$ This is very challenging for Political Marxism to accept, but perhaps the different directions taken currently, i.e. Knafo and Teschke's 'radical historicism' and the Brennerian 'rules of reproduction' can each find ways to make sense of the connections between circulation and production that the first category of authors want to emphasise. In spite of the analytical juncture, which in no doubt exists and will need to be further understood and dissected, there are inevitable parallels and encounters between these different approaches, which suffer more from abstract disagreements than from major empirical contradictions. More constructive dialogue about the overlaps and differences between the empirical specificities of these different approaches is much needed and should be actively encouraged.

In effect, the siloed nature of academic knowledge production is often a cycle that begins with a significant advance or breakthrough in a field or a particular question (e.g. Political Marxism 1.0 with its founders and their breakthrough in understanding the origins of capitalism). This generates reactions, which fall into broadly two camps, followers and foes. The followers then

${ }^{21}$ Campling \& Colás (2021: 59-60)

22 e.g. Banaji, 2011; Linebaugh \& Rediker, 2012; Moore, 2015; Khalili, 2019; Federici, 2004; Arrigui, 1994; Brandon, 2015 (see Brandon, 2011 for a critique of Political Marxism on the Dutch transition debate); Braudel, 1992 [1979]; Wallerstein, 1974.

${ }^{23}$ Campling \& Colás (2021: 59-60) 
break out into different directions, applying the breakthrough to different cases, exploring its potential, nuancing and clarifying it (Political Marxism 2.0). These again produce new directions which produce a landscape that becomes 'less identifiable' and which is where we are now. Some will go for the middle ground between different positions, others will go back to the original founders, others will try and provide a new breakthrough. The obvious problem here is fragmentation of an already small circle of people, and the honing in on specific issues and abstract debates, thus potentially losing sight of the bigger picture.

However, this symposium hopes to show that some of these specific issues can also help to reshape the big picture and come back to the fundamentals of the original breakthrough. The question is: how relevant and still necessary is the original breakthrough? Is historicising the emergence of capitalism more a historical matter, or does it carry the political weight it did in the 1980s when the Thompson/Althusser debate was the ordre du jour?

The collaborative effort to work out problems through dialectical and dialogical analysis, whether it may seem overly conflictual to some, is crucial to the collective identity of a school, tradition, or variant, as long as the main goal remains shared and relevant to the current conjuncture.

Does the symposium provide all the answers to these difficult questions? Certainly not. We can only hope to open up a new range of questions or debates that take us a little forward in our trajectories, or a little sideways or even backwards if that seems more useful. After summarising each contribution below, the various contributions and directions the authors are taking to guide the above questions will hopefully become clearer.

Post, Lafrance, Žmolek, and Evans ${ }^{24}$ all share a stronger position against Knafo and Teschke that defends the concept and more structuralist approach of the rules of reproduction, albeit for various reasons. Post argues that the problem of structure and agency is based on rules of reproduction as mutually constituted scientific abstractions. He defends the use of structures (as encompassing 'social property relations and their rules of reproduction') as tools to capture the specific and major changes in modes of production while noting their differentiation from transhistorical laws of motion. ${ }^{25} \mathrm{He}$ puts forward, following Brenner, a useful formulation for this as the difference between 'changes within a system' and 'changes of system'. ${ }^{26}$ Post also argues that there is a difference between idealisations or abstractions, and their application. In practice, there is a variety of studies that account for the contingency Knafo and Teschke lament, and which mitigates any potential issues with or rigidity $\mathrm{n}$ the concept of rules of reproduction. For Post, Knafo and Teschke's proposal is voluntarist, descriptive, and moves dangerously close to the type of historiography that 'refuses to define capitalism', such as work associated with the 'New History of Capitalism'. ${ }^{27}$ Moreover, radical historicism fails to explain the origins of capitalism, i.e. how and why it happened. In contrast, he argues that rules of reproduction help to explain the contingency of capitalism in the context of the survival of feudalism.

\footnotetext{
${ }^{24}$ Post, 2021; Lafrance, 2021; Žmolek, 2021; Evans 2021.

25 Post, 2021: 5.

26 Post, 2021: 3.

27 Post, 2021: 9.
} 
Lafrance takes a different angle but agrees largely with Post's analysis. For him, modes of production should be understood as bundles of political and social relationships, while structures, for Political Marxists working under the strong influence of E.P. Thompson, should be defined as alienated social relations. Agency and class struggles have a contingent role in structured historical processes. In other words, in on sense Lafrance turns the vocabulary and syntax around to show how structuralism is not problematic if appropriately handled and situated in the Political Marxist conceptual matrix. For him, historicism implies historically specific logics of modes of production as sets of social property relations. Lafrance discusses Thompson's work in detail, followed by Marx in Capital through Hegel to emphasise that social property relations are structured by rules of reproduction, and determine a mode of production's specific 'laws of motion', thereby allowing for Brenner and Wood's critique of the superstructuralism of authors such as G. A. Cohen. ${ }^{28}$ Lafrance retraces how the concept of social property relations enables an analysis of the contingency of pre-capitalist class relations as alienated, but that it is essential to also recognise that 'capitalist markets do not work as any other social realm' and that refusing to acknowledge this is equivalent to falling back into Weberian historical sociology. ${ }^{29}$

Žmolek strongly disagrees with Knafo and Teschke's reading and critique of aspects of Brenner and Wood's work and takes them to task for not sufficiently demonstrating the 'intent' of this structuralism. He categorically denies any such intent or reification of social relations in Brenner and Wood that might go against the main purposes of Political Marxism. He laments the abstract level of the discussion and suggests Knafo and Teschke's disciplinary context International Relations - might explain their specific antipathy to, and conceptualisation of, structuralism. By dissecting some of Knafo's earlier work on agency, Žmolek argues that questions remain open as to its meaning and how to operationalise such a critique. He suggests that it is impossible to engage in the social sciences or humanities without being imbricated in the (potentially reifying) language of institutions and social relations, of "structures". ${ }^{30}$ Moreover, Žmolek is concerned with a potential implication of Knafo and Teschke's argument for the generalisation of market dependence, and more importantly perhaps, with the focus on method and critique of one's foundations, which he fears may be detrimental to new readers of Political Marxism.

Evans also finds Knafo and Teschke's critique problematic and misplaced, though she acknowledges that issues of 'formalism, ahistoricism and structuralism' can be found in certain arguments of Wood regarding race and gender, for example. ${ }^{31}$ Nevertheless, she argues that other theoretical solutions, at the opposite of what Knafo and Teschke propose, can also help resolve some of these tensions, and avoid the risks of de-politicization of capitalism and exploitation she worries might derive from the concept of radical agency. Evans proposes Uneven and Combined Development (UCD) as a theoretical arsenal to retrieve the 'practices' that she agrees can be found missing. To do so, she argues that it is not possible to do without the concept of modes of production, which through the method of UCD can provide the notion of a 'generalized' system of 'rules and compulsions' in which empirical specificities are then more easily attended to. ${ }^{32}$ Evans uses the case of settler-colonial Canada to show how she

\footnotetext{
${ }^{28}$ Lafrance, 2021: 7-9

${ }^{29}$ Lafrance, 2021: 16; original emphasis.

30 Žmolek, 2021: 9.

${ }^{31}$ Evans, 2021: 2

32 Evans, 2021: 5.
} 
navigates a UCD/Political Marxist analysis and what it can bring to such a different case to the standard Political Marxist narratives on England and Western Europe. Through the agency of Indigenous and migrant communities, the innovation of 'personalized stratifications' based on race, and the unintended outcomes of a wage-labour market characterised by unfreedom, Evans provides an alternative interpretation to and application of Knafo and Teschke's tripartite model of radical historicism. ${ }^{33}$

Moreno Zacarés and Salgado ${ }^{34}$ provide more sympathetic contributions to Knafo and Teschke's proposal of a radical historicism. Nevertheless, they propose alternative interpretations of what is at stake and how to navigate the debate. Moreno Zacarés argues that the structuralist-historicist divide is misleading because it is made in more ontological rather than methodological terms, and that the debate should be reformulated as a 'spectrum' between a structural and institutional historicism. Moreno Zacarés traces echoes of the debate in the history of social sciences - specifically in the Methodenstreit - and his piece also works to situate Knafo and Teschke's work in a broader disciplinary context that reads them as reflecting more of an 'institutionalist bent'. ${ }^{35}$ Finally, Moreno Zacarés takes on the question of market dependence and argues that it should not be abandoned as a 'source of determinist bias', as suggested by Knafo and Teschke. ${ }^{36}$ Instead, by going back to the Brenner-WoodPost debate on the Dutch transition, Moreno Zacarés proposes to follow Wood in taking a 'institutional historicist' line and use the concept of market dependence in a more indeterminate sense that can outline 'the necessary conditions for capitalist development (e.g. money, market dependence, price competition, etc.) but leaves an unspecified variable around the sufficient causes for this transformation'. ${ }^{37}$

Salgado also broadens the debate, this time to a non-Anglophone post- and decolonial audience, which often dismisses, along with a range of Marxist authors, Political Marxist arguments as Eurocentric. Instead, he argues that radical historicism is a useful method that can retrieve forms of agency that post- and decolonial authors also lament as missing in histories of capitalism. While being careful to show the different lineages of post- and decolonial theory, Salgado shows the parallels between radical historicism and Chakrabarty and Dussel's rejection of Eurocentrism. He defends how this approach contextualises class 'as a set of social practices of (re)production and exploitation', and how a welcome methodological - rather than ontological - 'emphasis on agency puts the notion of historical processes and disputes between collective actors at the core of a genealogical conception of these same actors'. ${ }^{38}$ Salgago engages explicitly with the notion of subjectivity, which, as I noted above, is a central yet largely unacknowledged dimension in this debate. He argues by discussing Dussel, Quijano, Castro-Gómez, and Grosfoguel - that if 'we can often find an accommodation of Marxist structuralism in Decolonial thought', it often 'ultimately falls back to abstract notions [of] subjectivity through the "colonial divide"'. ${ }^{39}$ Nevertheless he also draws the ways in which both this tradition and radical historicism contribute to moving beyond Eurocentrism as they return 'to the discussion on statehood by emphasising the crucial role of

\footnotetext{
33 Evans, 2021: 20.

34 Moreno Zacarés, 2021; Salgado, 2021.

35 Moreno Zacarés, 2021: 15

36 Moreno Zacarés, 2021: 26

37 Moreno Zacarés, 2021: 35

38 Salgado, 2021: 6.

39 Salgado, 2021: 18.
} 
(geo)politics on practices of accumulation and reproduction', building on his own work on Brazilian state-formation. ${ }^{40}$

Finally, Gerstenberger ${ }^{41}$ provides a very useful addition to the above contributions by providing a larger sketch of Marxist historiographical issues today. As a major Marxist historian who has often critically and sympathetically engaged with Political Marxism and historical sociology more broadly, ${ }^{42}$ she argues that the debate in this symposium reflects a larger issue about the relationship between theory and empirics, and how Marxism gets lost in the 'calamities' of theoretical explanation and illustration rather than open-ended 'testing'. This issue of knowledge production relates to the discussion in this introduction and the question of what differentiates Marxist historiography from the broader social sciences and humanities. By first discussing a range of 'cornerstones of Marxist historical theory' such as the mode of production and the question of unfree labour, Gerstenberger then moves to approaches that focus on the specificities of capitalism and raises the debate first with Banaji and his concept of commercial capitalism as an illustration of the problems with transhistorical concepts, and secondly with Pashukanis and Miéville on the bourgeois state form. Thirdly, Gerstenberger discusses UCD as a problematic transhistorical approach that anachronistically internationalises nation-state relations. Finally, if she concludes by discussing Knafo and Teschke's intervention as a convincing critique of a problematic functionalism in the founders of Political Marxism, she remains unconvinced that this critique is a solution to Marxist historiography's list of calamities generated by the agency-structure debate. Raising the issue of 'contingency' following Tzouvala's work, Gerstenberger emphasises the 'differentiation between historical forms of capitalism and basic conditions for the reproduction of the capital relation' as a necessary analytical strategy. ${ }^{43}$ For example, this allows her to suggest, taking on the themes of agency and structure through an empirical focus, a definition of racism as a 'competence to command the concrete employment of the capacity to labour of human beings' while asserting that the 'limitation of state power is a requisite for the reproduction of capitalism and one of the defining elements of capitalist state power. ${ }^{.44}$

We close the symposium with Knafo and Teschke's reply to their critics. ${ }^{45}$ They provide a thorough and deep reply to each contributor, clarify some misunderstandings, and rephrase in helpful ways what is at stake in their contribution by illustrating their previously more abstract argument through various historical cases. The discussions of theory, structure, Thompson and Wood, and of certain key historical cases such as the periodisation of feudalism, the specificity of settler-colonialism in Canada, and the development of capitalism in post-war US, Germany and East Asia respond directly to points raised by Post, Lafrance, Evans, and Žmolek. They close by first clarifying the point raised by several contributors, that the radical historicism they propose is meant in a methodological, and not ontological, sense. Second, they reiterate their emphasis on agency, the issue at the absolute core of this debate, by comparing it to power and its dualities, and hence highlighting agency's interchangeability with

\footnotetext{
40 Salgado, 2021: 31.

41 Gerstenberger, 2021

42 Gerstenberger, 2007. For example, in the following piece, Gerstenberger raises again the issue of a 'European Ancien Régime' as a counter-argument to the Brenner-Wood transition from feudalism account (2021: 18-22).

43 Tzouvala, 2020; Gerstenberger, 2021: 30.

44 Gerstenberger, 2021: 31.

45 Knafo \& Teschke, 2021b.
} 
structures or constraints. Crucially, their argument lies in how, methodologically, focusing on the agency side of the coin produces accounts about the 'making of history', rather than its consequences, which instead 'do not tell us enough about what is going on'. ${ }^{46}$

To conclude this introduction, it is important to return to some of the history of the journal Historical Materialism itself, since this symposium also illustrates its origins and expansion, and its 'social lineages', if not 'rules of reproduction'. Indeed, both Knafo and Teschke were key participants in the origins and establishment of the journal and the project in which they publish these pages today. Set in the context of a vibrant Marxist London scene in the late 1990s, with a range of Marxist doctoral students at the London School of Economics, the journal set out to be a non-sectarian space that does 'not favour any one tendency, tradition or variant' and for which 'notwithstanding the variety of its practical and theoretical articulations, Marxism constitutes the most fertile conceptual framework for analysing social phenomena, with an eye to their overhaul.' 47 Political Marxism has always been given a platform in the journal, opening its first issue with an article by Ellen Meiksins Wood, followed by two issues dedicated to Robert Brenner's 'second debate' of 'the post-war history of world capitalism and of the Marxist theory of crisis' two years later, ${ }^{48}$ as well as many key texts in the journal and book series in the last three decades. ${ }^{49}$

Knafo and Teschke's work at the University of Sussex since the early 2000s has since played a major role in forming new generations of Marxist students in International Relations and International Political Economy, of which Javi Moreno Zacarés, Pedro Salgado, and myself are some of the products. My involvement as an editor of the journal since 2015 has aimed to give a louder voice to Political Marxism and to historiography on the editorial board, in the journal and at the conferences. This symposium, alongside the fundamental participation of the contributors in various ways along the years, especially Charlie Post and Heide Gerstenberger as two of its key supporters, is, I hope, a sign of this objective coming to fruition.

The symposium is also the fruit of various panels at the Historical Materialism London conferences, from 2016 to 2019, where the participants below and others have contributed to these debates in various panels. Some were organised around the many legacies of Ellen Meiksins Wood, lost to us so sadly in 2016. Other panels covered the ongoing Brenner debates, the discussions with proponents of UCD, for which we continue to mourn the tragic loss of our comrade Neil Davidson in 2020, and the more recent debates around structuralism and the concept of rules of reproduction. ${ }^{50} \mathrm{We}$ also want to acknowledge here the legacy of

\footnotetext{
46 Knafo \& Teschke, 2021b: 23-24. Original emphasis.

47 https://www.historicalmaterialism.org/node/59

48 Wood, 1996; Historical Materialism 4.1, 1999; Historical Materialism 5.1, 1999.

49 Wood, 2002a; Wood, 2002b; Wood, 2006: Wood, 2007; Wood, 2016; Teschke, 2005; Post, 2011a; Post, 2011b; for a critique of Banaji, see Post, 2013; Žmolek, 2014; Lafrance, 2019; Patriquin, 2012; Dimmock, 2014. See also Pal (2018) and the debate in a symposium in Historical Materialism 26.3 on Alex Anievas and Kerem Nişancioğlu's (2015) How the West Came to Rule, taking, among others, Political Marxism to task from an Uneven and Combined Development perspective, contributing to a major debate which has significantly shaped discussions in recent years, and which cannot be adequately covered in this short space.

50 See the symposium on Neil Davidson's (2012) How Revolutionary Were the Bourgeois Revolutions? in Historical Materialism 27.3 with contributions by Post (2019) and Gerstenberger (2019).
} 
Colin Barker's historical contributions, also lost to us in 2019. ${ }^{51}$ There is a need to maintain the flame of these towering figures, for their unending academic and political commitments, lost to the field too soon and to which we dedicate this symposium. We hope in some sense at least to do justice to their work in what follows.

If one of the roles of the journal Historical Materialism is to bridge, bring together, and give a sense of common purpose to various Marxist tendencies and debates, this noble purpose may also have its downsides. It can sometimes push editors to overly seek common ground, or neutralise and marginalise positions that take a specific stance. Striking that balance is a continuous challenge, and this symposium is one way to show that it is possible to have pointed and stark disagreements as a collective, while working together to understand and take further the pursuit of rigorous and ruthless 'criticism of all that exists'. This pursuit is here defined, for Political Marxists, according to some baseline objectives, i.e. developing an understanding and explanation of capitalism, what came before and hopefully what will come next, according to contested social property relations that are never pre-determined. Whether you decide to be more of a radical historicist, or defend the concept of rules of reproduction, or are looking for another way to further the previous objective, we hope you will help us to shape future conversations.

\section{Bibliography}

Anievas, Alex. \& Nişancioğlu, Kerem. 2015, How the West Came to Rule: The Geopolitical Origins of Capitalism, London: Pluto

Arrighi, Giovanni 1994, The Long Twentieth Century: Money, Power, and the Origins our Time, London: Verso

Aston, Trevor Henry and C.H.E. Philpin (eds.) 1985, The Brenner Debate: Agrarian Class Structure and Economic Development in Pre-industrial Europe, Cambridge:

Cambridge University Press.

Banaji, Jairus. 2011, Theory as History: Essays on Modes of Production and Exploitation, Leiden: Brill

Barker, Colin. 1997. 'Some reflections on two books by Ellen Wood', Historical Materialism, 1(1), 22-65

Barker, Colin. Dale, Gareth. \& Davidson, Neil. (eds.) 2021, Revolutionary Rehearsals in the Neoliberal Age, Haymarket

Brandon, Pepjin. 2015, War, Capital, and the Dutch State (1588-1795), Leiden: Brill

2011, 'Marxism and the "Dutch Miracle": The Dutch Republic and the Transition Debate', Historical Materialism, 19(3), 106-146

Braudel, Fernand. 1992 [1979], Civilization and Capitalism, 15th-18th Century, translated by Siân Reynolds, 3 vols., Harper Collins

${ }^{51}$ For one of the best critiques of Ellen Meiksins Wood's work, see Barker (1997) and more recently, a posthumous publication by Barker, Dale \& Davidson (2021). 
Brenner, Robert. 1976, 'Agrarian Class Structure and Economic Development in Pre-Industrial Europe', Past and Present, 70

1977, 'The Origins of Capitalist Development: A Critique of Neo-Smithian Marxism', in New Left Review, 104, 25-92

2007, 'Property and Progress: Where Adam Smith Went Wrong', in Chris Wickham (ed), Marxist History-writing for the Twenty First Century, Oxford: Oxford University Press, 49-111

Campling, Liam. \& Colás, Alex. 2021, Capitalism and the Sea, London: Verso

Davidson, Neil 2012, How Revolutionary Were The Bourgeois Revolutions?, Chicago: Haymarket Books.

Dimmock, Spencer. 2014, The Origin of Capitalism in England 1400-1600, Leiden: Brill

Evans, Jessica. 2019. Colonialism(s), Race, and the Transition to Capitalism in Canada. In (Eds. Post, C. and LaFrance, X.) Case Studies in the Origins of Capitalism, 191-213, Palgrave, Macmillan.

2021, 'Mediating Capitalism's 'Rules of Reproduction' with Historical Agency: Political Marxism, Uneven and Combined Development and Settler-Capitalism in Canada', Historical Materialism, 29.3

Federici, Sylvia 2004, Caliban and the Witch, New York: Autonomedia.

Gerstenberger, Heide. 2007 [1990] Impersonal Power. History and Theory of the Bourgeois State, Leiden: Brill 27(3), 191-209.

2019. 'How Bourgeois Were the Bourgeois Revolutions?', Historical Materialism,

2021, 'On stepping stones and other calamities of Marxist historiography', Historical Materialism, 29.3

Khalili, Laleh. 2019, Sinews of War and Trade: Shipping and Capitalism in the Arabian Peninsula, London: Verso

Knafo, Samuel 2013, The Making of Modern Finance: Liberal Governance and the Gold Standard, London: Routledge.

Knafo, Samuel. \& Teschke, Benno. 2021a, 'Political Marxism and the Rules of Reproduction of Capitalism: A Historicist Critique', Historical Materialism, 29.3 Materialism, 29.3

2021b, 'The Antinomies of Political Marxism: a Historicist Reply to Critics', Historical Lafrance, Xavier. 2019, The Making of Capitalism in France, Leiden: Brill

2021, 'The Vacuity of Structurelessness: Situating Agency and Structure in Exploitative and Alienated Social Relations', Historical Materialism, 29.3 
Lafrance, Xavier. \& Post, Charles. (eds.) 2019a, Case Studies in the Origins of Capitalism, London: Palgrave

Lafrance, Xavier. \& Post, Charles. 2019b, 'Introduction', in Xavier Lafrance \& Charles Post (eds.), Case Studies in the Origins of Capitalism, London: Palgrave, 1-38

Linebaugh, Peter. \& Rediker, Marcus. 2012, The Many-Headed Hydra: The Hidden History of the Revolutionary Atlantic, London: Verso

Mau, Søren. 2021 “The Mute Compulsion of Economic Relations': Towards a Marxist Theory of the Abstract and Impersonal Power of Capital', Historical Materialism, 29.3

Mooers, Colin. 1991, The Making of Bourgeois Europe: Absolutism, Revolution and the Rise of Capitalism in England, France and Germany, London: Verso

Moore, Jason, 2015, Capitalism in the Web of Life: Ecology and the Accumulation of Capital, London: Verso

Moreno Zacarés, Javier. 2018, 'Beyond Market Dependence: The Origins of Capitalism in Catalonia', Journal of Agrarian Change, 18, 749-767

2021, 'Two Historicisms: Unpacking the Rules of Reproduction Debate', Historical Materialism, 29.3

Pal, Maïa. 2018 'My Capitalism Is Bigger than Yours! Against Combining "How the West Came to Rule" with "the Origins of Capitalism"', Historical Materialism, 26(3), 99-124

Patriquin, Larry 2012, 'Introduction: The "Method" of Ellen Meiksins Wood', in The Ellen Meiksins Wood Reader, edited by Larry Patriquin, Historical Materialism Book Series, Leiden: Brill.

Post, Charles. 2011a, The American Road to Capitalism: Studies in Class Structure, Economic Development and Political Conflict 1620-1877, Leiden: Brill

2011b, 'Social-Property Relations, Class-Conflict and the Origins of the US Civil War: Towards a New Social Interpretation, Historical Materialism, 19(4), 129-168

2013, 'Capitalism, Laws of Motion and Social Relations of Production', Historical Materialism, 21(4), 71-91

2019. 'How Capitalist Were the 'Bourgeois Revolutions'?, Historical Materialism, 27(3), 157-190

2021, 'Structure and Agency in Historical Materialism: A Response to Knafo and Teschke', Historical Materialism, 29.3

Salgado, Pedro. 2020, 'Agency and geopolitics: Brazilian formal independence and the problem of Eurocentrism in international historical sociology', Cambridge Review of International Affairs, 33:3, 432-451

2021a, 'The transition debate in Brazilian history: The bourgeois paradigm and its critique', Journal of Agrarian Change, 21(2), 263-284 
2021b, 'Anti-Eurocentric Historicism: Political Marxism in a broader context', Historical Materialism, 29.3

Sørensen, Esben Bøgh. 2019, 'The Making of Agrarian Capitalism: Social Relations and Economic culture in Sixteenth and Seventeenth Century England', Ph.D. dissertation, Aarhus University, Denmark.

2021, 'To be bold of one's own: agrarian capitalism and household management in Thomas Tusser's Five Hundred points of good husbandry', Cultural and Social History, Advance Online

Souvlis, George. (ed.) 2019, Voices on the Left: Challenging Capitalist Hegemony, Athens: Red Marks

Teschke, Benno. 2003, The Myth of 1648: Class, Geopolitics, and the Making of Modern International Relations, London: Verso

2005, 'Bourgeois Revolution, State-Formation and the Absence of the International', Historical Materialism, 13(2), 3-26

2020, 'The Social Origins of $18^{\text {th }}$ Century British Grand Strategy: a Historical Sociology of the Peace of Utrecht', in Alfred H. A. Soons (ed.) The 1713 Peace of Utrecht and its Enduring Effects, Leiden: Brill, 120-155

Tzouvala, Ntina. 2020, Capitalism as Civilisation: A History of International Law, Cambridge: Cambridge University Press

Wallerstein, Immanuel. 1974, The Modern World-System I: Capitalist Agriculture and the Origins of the European World-Economy in the Sixteenth Century, New York: Academic Press

Wood, Ellen Meiksins 1981, 'The Separation of the Economic and the Political in Capitalism', New Left Review, I, 127: 66-95.

1995, Democracy against Capitalism: Renewing Historical Materialism, Cambridge:

Cambridge University Press.

1996, 'The Non-history of Capitalism', Historical Materialism, 1, 1: 5-21.

2002a 'Infinite War', Historical Materialism, 10(1), 7-27.

2002b 'Landlords and Peasants, Masters and Slaves: Class Relations in Greek and Roman Antiquity', Historical Materialism, 10(3), 17-69

2006, 'Logics of Power: A Conversation with David Harvey', Historical Materialism, 14(4), 9-34

2007, 'A Reply to Critics', Historical Materialism, 15(3), 143-170 
2016, 'Britain versus France: How Many Sonderwegs?', Historical Materialism, 24, 1: 11-29.

Žmolek, Michael. 2014, Rethinking the Industrial Revolution: Five Centuries of Transition from Agrarian to Industrial Capitalism in England. Leiden: Brill

2021, ' On 'the problem with Brenner: The Paradox of Agency and the Heresy of Reification', Historical Materialism, 29.3 